\title{
The Carlisle Site (41WD46), a Middle Caddoan Occupation on the Sabine River, Wood County, Texas
}

Timothy K. Perttula

Heritage Research Center, Stephen F. Austin State University

Bob D. Skiles

Bonnie C. Yates

Follow this and additional works at: https://scholarworks.sfasu.edu/ita

Part of the American Material Culture Commons, Archaeological Anthropology Commons, Environmental Studies Commons, Other American Studies Commons, Other Arts and Humanities Commons, Other History of Art, Architecture, and Archaeology Commons, and the United States History Commons

Tell us how this article helped you.

This Article is brought to you for free and open access by the Center for Regional Heritage Research at SFA ScholarWorks. It has been accepted for inclusion in Index of Texas Archaeology: Open Access Gray Literature from the Lone Star State by an authorized editor of SFA ScholarWorks. For more information, please contact cdsscholarworks@sfasu.edu. 


\section{The Carlisle Site (41WD46), a Middle Caddoan Occupation on the Sabine River, Wood County, Texas}

\section{Creative Commons License}

\section{(c) (1) \&}

This work is licensed under a Creative Commons Attribution-NonCommercial 4.0 International License 


\title{
The Carlisle Site (41WD46), a Middle Caddoan Occupation on the Sabine River, Wood County, Texas
}

\author{
Timothy K. Perttula \\ Bob D. Skiles \\ and \\ Bonnie C. Yates

\section{INTRODUCTION AND SETTING}

The Carlisle site (41WD46) is located on the Sabine River near its confluence with Lake Fork Creek in the Upper Sabine River Basin. As defined by Perttula et al. (1986), the Upper Sabine River Basin includes the area from the headwaters of the Sabine River to the mouths of Cherokee Bayou and Hatley Creek at the western edge of the Sabine Uplift (Bureau of Economic Geology 1965). Lake Fork Creek is one of several large southsoutheastward flowing streams within the Upper Sabine River Basin. The town of Mineola is approximately 13 kilometers $(\mathrm{km})$ west of the Carlisle site.

The site is situated at the tip of an upland projection overlooking the Sabine River floodplain, but extends into the floodplain to within ca. 30 meters of the river bank (Figure 1). The Lake Fork Creek channel is approximately one $\mathrm{km}$ east of the site.

While the site was an improved pasture for many years prior to 1975 and to the present, it had been previously cultivated. In fact, this cultivation may have contributed to its initial identification in the early 1930s (see below), as well as its subsequent partial burial. The upland sandy soils derive from the Queen City Formation, and these are highly susceptible to erosion and colluvial downwasting. Colluvial deposition seems to have been a prominent factor in the burial of cultural materials along valley margins and lower footslopes elsewhere in the Upper Sabine Basin (Perttula et al. 1986), and the site's topographic position suggests that both alluvial and colluvial deposition is responsible for the burial of the floodplain cultural deposits at the Carlisle site.

\section{HISTORY OF INVESTIGATIONS}

The Carlisle site was initially recorded in 1930 by A.T. Jackson as a "dense midden deposit; many mussel shells" on the Harry Meredith farm (Wilson and Jackson 1930). When the site was re-recorded in 1975 , the midden deposits were not visible on the surface and were exposed only in coring activities near the bank of the Sabine River. The midden deposits (here labelled Area B) were covered with ca. $20 \mathrm{~cm}$ of sterile overburden (Skiles et al. 1980). A second area of concentrated cultural deposits was identified on the adjacent upland projection elevated about five $m$ above the Sabine River floodplain (Area A). 


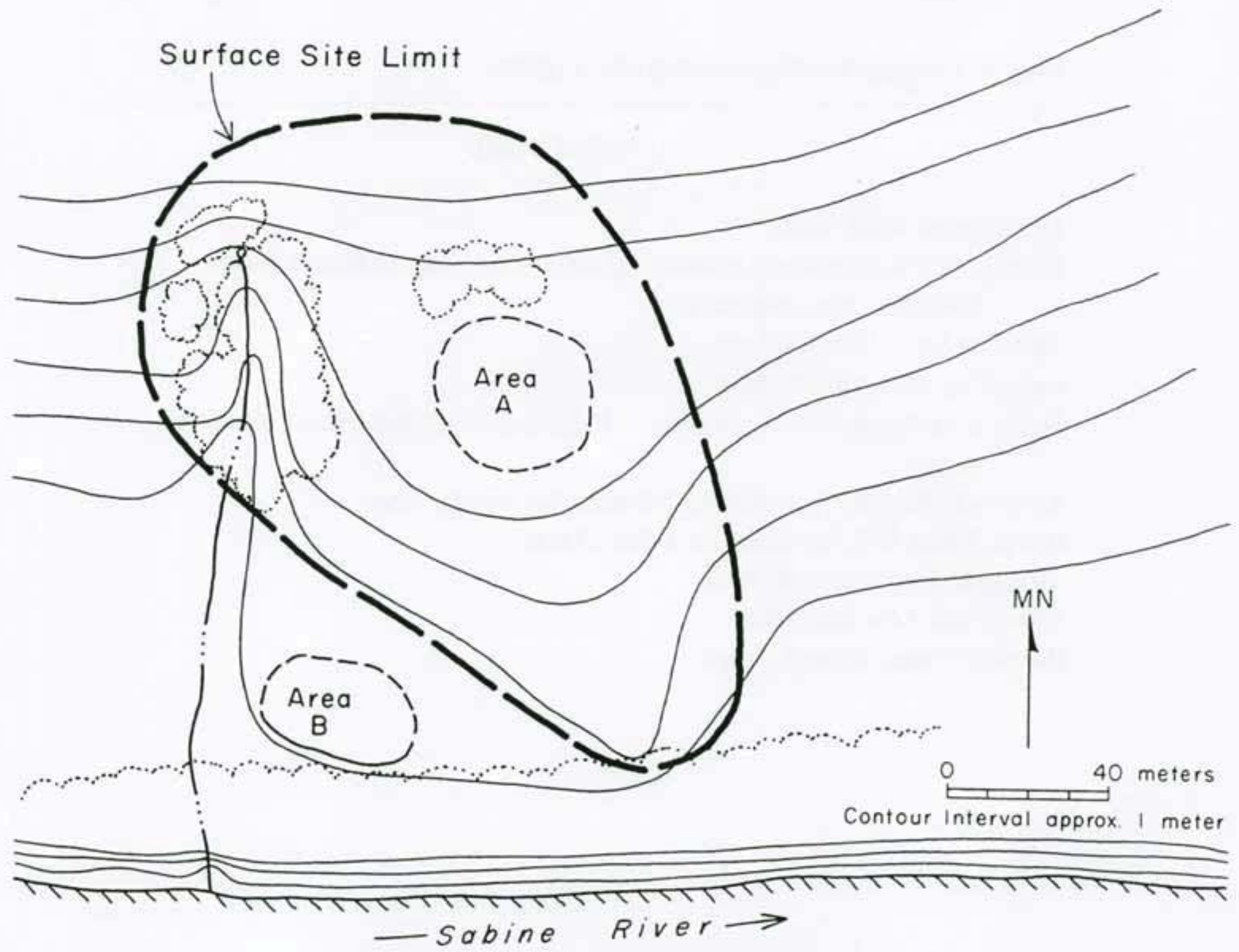

Figure 1. General Map of the Carlisle Site.

Test excavations were carried out in both areas of the site in 1975 by Skiles. In Area A Skiles excavated six $1 \times 1 \mathrm{~m}$ test units to sample the deposits on the upland landform, and two $50 \times 50 \mathrm{~cm}$ shovel tests were also excavated there in 1975 and 1986 (Figure 2). Although no obvious features or concentrations of cultural materials were encountered in the Area A excavations, most of the materials recovered (such as pieces of daub, a mud-dauber nest, and several large sherds from refired brushed and incised vessels) suggest that a Caddoan structure stood upon the crest of the upland projection. 


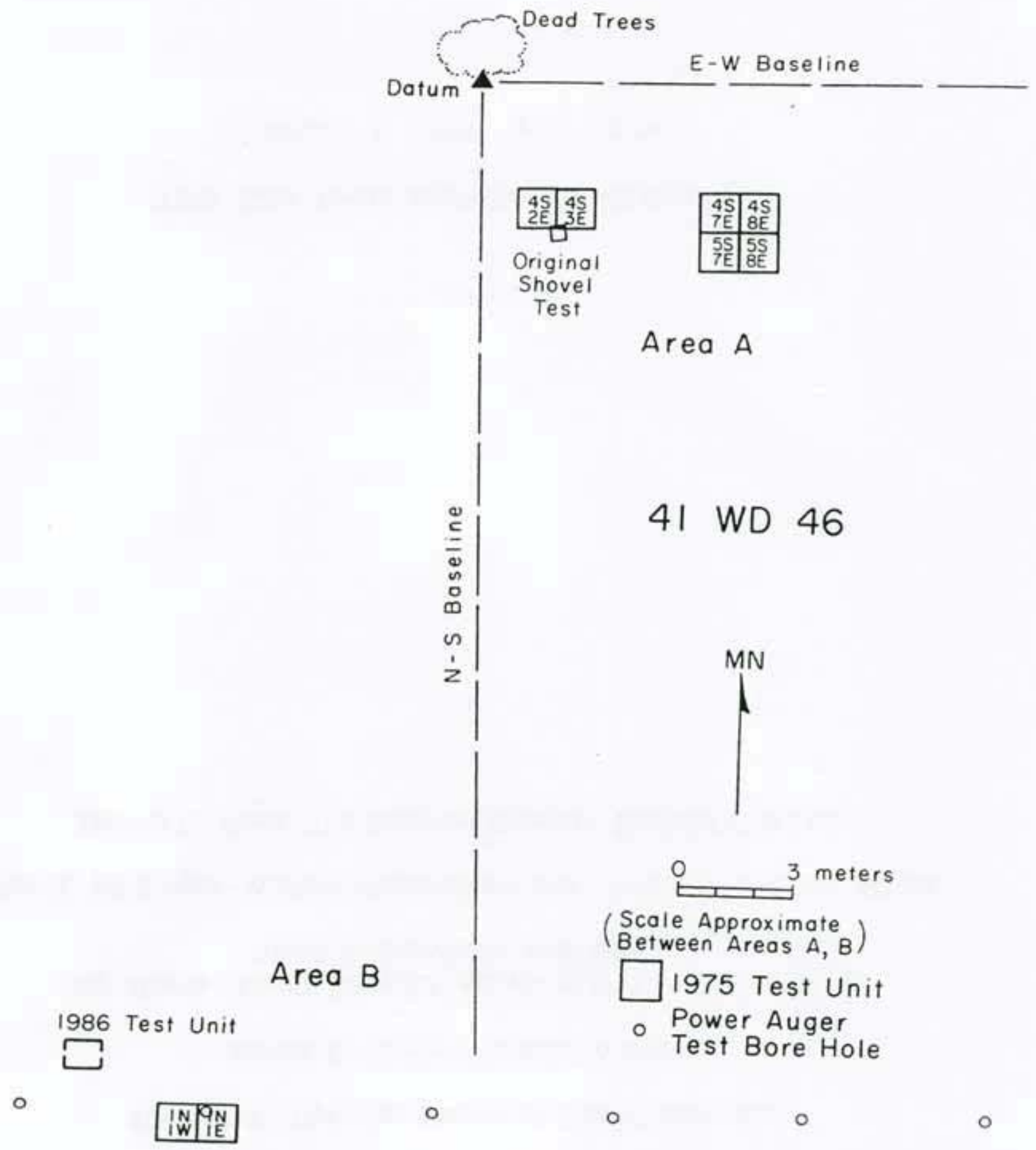

Figure 2. Plan of Site Excavations.

In 1975 a series of power augur holes excavated in Area B located a buried midden deposit at the site. Skiles excavated a $1 \times 2 \mathrm{~m}$ unit in the midden in 1975 (see Figure 2), but because of the density of burned and unburned shell, the units were terminated prior to reaching sterile subsoil. Several thousand mussel shells were recovered in the midden, but 
were never properly studied as they were lost after being sent to Southern Methodist University for study.

More recently, the Carlisle site was revisited in January and March of 1986 as part of the archaeological reconnaissance of the proposed Waters Bluff Reservoir (Perttula 1986). As planned, this reservoir would cover a large area of the Sabine River floodplain in Wood and Smith counties, Texas, and at maximum floodpool levels (303 feet msl) would inundate the Carlisle site floodplain midden deposits.

Shovel testing in 1986 suggested that the midden may have been buried by as much as $50 \mathrm{~cm}$ of sand. The completion of an additional $1 \times 1 \mathrm{~m}$ unit in March 1986 uncovered midden debris between ca. $20-25$ to $55 \mathrm{~cm}$ below surface (Figure 3). Striae of pale brown sand within the midden indicates that alluvial and/or colluvial deposition occurred during the formation of the Caddoan floodplain midden deposits. The vast majority of the Area B cultural materials were recovered in the plow zone and the buried midden. An occupational surface was recognized between ca. $25-35 \mathrm{~cm}$ (labelled Feature 1) in the midden. It was defined by a concentration of large ceramic sherds, many complete mussel shell valves, and turtle shell fragments all lying on a common horizontal plane. Charcoal from Feature 1 was dated to $540+/-60$ years B.P. (Beta-17494). Feature 1 in the 1986 investigations may be part of the larger shell concentration encountered in the 1975 work by Skiles, which is suspected to have been deposited in a large pit.

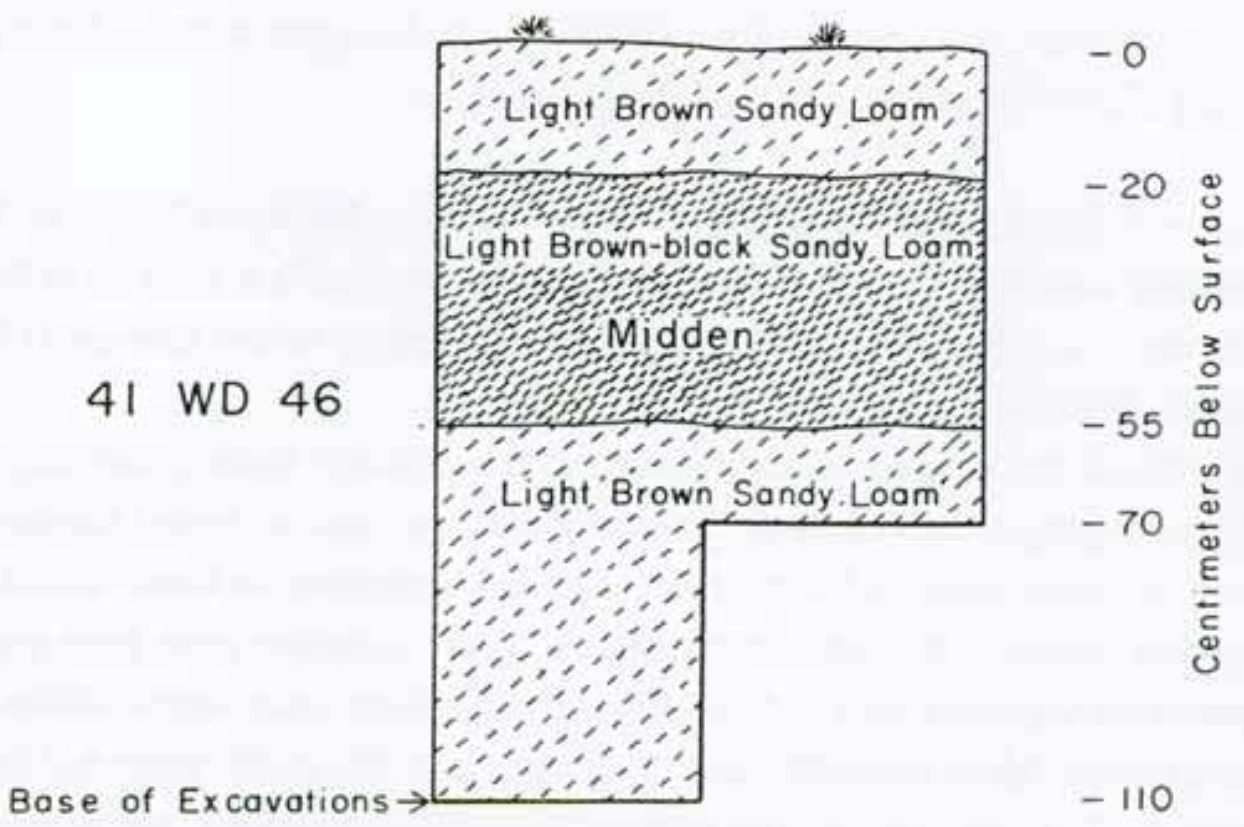

Figure 3. Area B Midden Profile. 
Mussel shells are a consistent component in Caddoan middens in the Upper Sabine River Basin that predate ca. A.D. 1400, with substantial quantities being recovered from excavations at sites such as Taddlock (41WD482), Son Gibson (41WD1), and 41WD36, all dating to the Early Caddoan period. Nevertheless, the absolute quantity and context of the mussel shell at Carlisle (i.e., a $30 \mathrm{~cm}$ thick, homogeneous lens) is very different from other Upper Sabine River basin middens.

\section{ARTIFACT ASSEMBLAGES}

A wide variety of artifacts was found at the Carlisle site in the 1975 and 1986 investigations (Table 1). Plain and decorated ceramic sherds and lithic debitage were the most common types of artifacts present at the site, followed by unifacial lithic tools, bifaces and biface fragments, and dart projectile points. Most of the materials were collected from the Area A knoll and the general surface, particularly the lithic tools and debris, while ceramic sherds and daub comprised 85 percent of the artifacts from the Area B midden (see Table 1).

Table 1. Artifact Assemblages

\begin{tabular}{|c|c|c|c|c|}
\hline Artifact Classes & Area A & General Surface & Area B & Total \\
\hline Ceramics & 119 & 168 & 329 & 616 \\
\hline $\begin{array}{l}\text { Daub } \\
\text { Burned Clay }\end{array}$ & 1 & 3 & 7 & $\begin{array}{r}10 \\
1\end{array}$ \\
\hline $\begin{array}{l}\text { Cores } \\
\text { Thin Bifaces } \\
\text { Thick Bifaces } \\
\text { Biface Fragments }\end{array}$ & $\begin{array}{l}8 \\
1 \\
5 \\
7\end{array}$ & $\begin{array}{l}11 \\
16 \\
17 \\
12 .\end{array}$ & 1 & $\begin{array}{l}22 \\
17 \\
22 \\
20\end{array}$ \\
\hline $\begin{array}{l}\text { Dart Points } \\
\text { Arrow Points }\end{array}$ & $\begin{array}{r}10 \\
4\end{array}$ & $\begin{array}{l}25 \\
10\end{array}$ & 1 & $\begin{array}{l}35 \\
15\end{array}$ \\
\hline $\begin{array}{l}\text { Perforator } \\
\text { Piece esquille } \\
\text { Unifacial Tools }\end{array}$ & 28 & $\begin{array}{r}1 \\
1 \\
37\end{array}$ & & $\begin{array}{r}1 \\
1 \\
65\end{array}$ \\
\hline $\begin{array}{l}\text { Debitage } \\
\text { Fire-cracked rock }\end{array}$ & $\begin{array}{r}324 \\
2\end{array}$ & 319 & $\begin{array}{l}38 \\
16\end{array}$ & $\begin{array}{r}681 \\
18\end{array}$ \\
\hline SUMMARY & 509 & 620 & 395 & 1524 \\
\hline
\end{tabular}




\section{Lithics}

Including fire-cracked rock, 838 lithic artifacts were recovered from surface collections and limited excavations in Area A of the Carlisle site. While most of the lithic artifacts are from the surface collections (see Table 1), lithic densities from subsurface contexts are about 70 artifacts per cubic meter.

Dart points, bifaces and biface fragments, and a variety of unifacial tools (three scrapers, two alternately retouched pieces, and 65 unifacially worn flakes) are well represented in the Area $\mathrm{A}$ artifact assemblage. In general, the high frequency of bifaces and biface fragments, as well as cores, and the common discarding of broken dart projectile points, indicates that the manufacture and refurbishing of bifacial tools was a common activity at the site.

The types of dart projectile points found at Carlisle (Table 2) suggest considerable use of the site during Archaic and Early Ceramic periods (Figure 4 and 5). Comer-notched, parallel-stemmed, and contracting-stem arrowpoints represent the use of the bow and arrow by the Caddoan occupants of the Carlisle site.

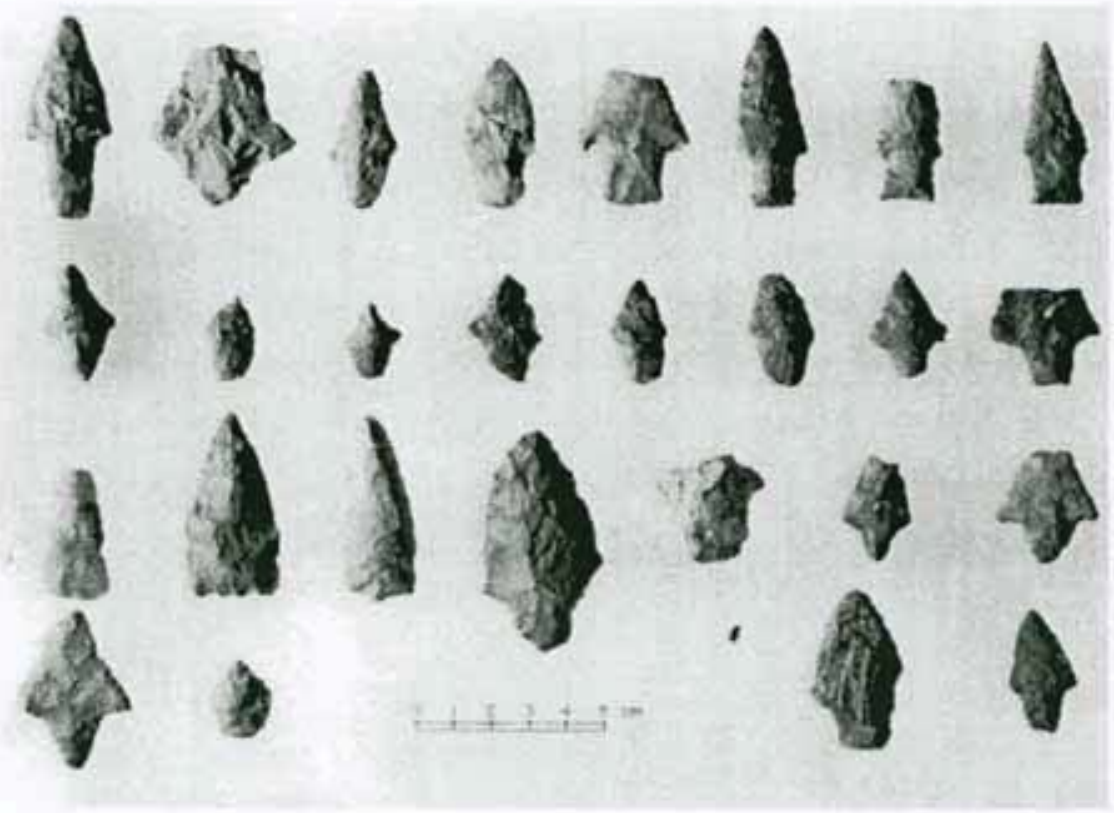

Figure 4. Dart Points from the General Surface: (top row, 1-r) Gary, Bulverde, and Yarbrough types, (second row, 1-r) Gary types, (third row, 1-r) Unidentified and Gary types, (bottom row, 1-r) Gary and Kent types. 


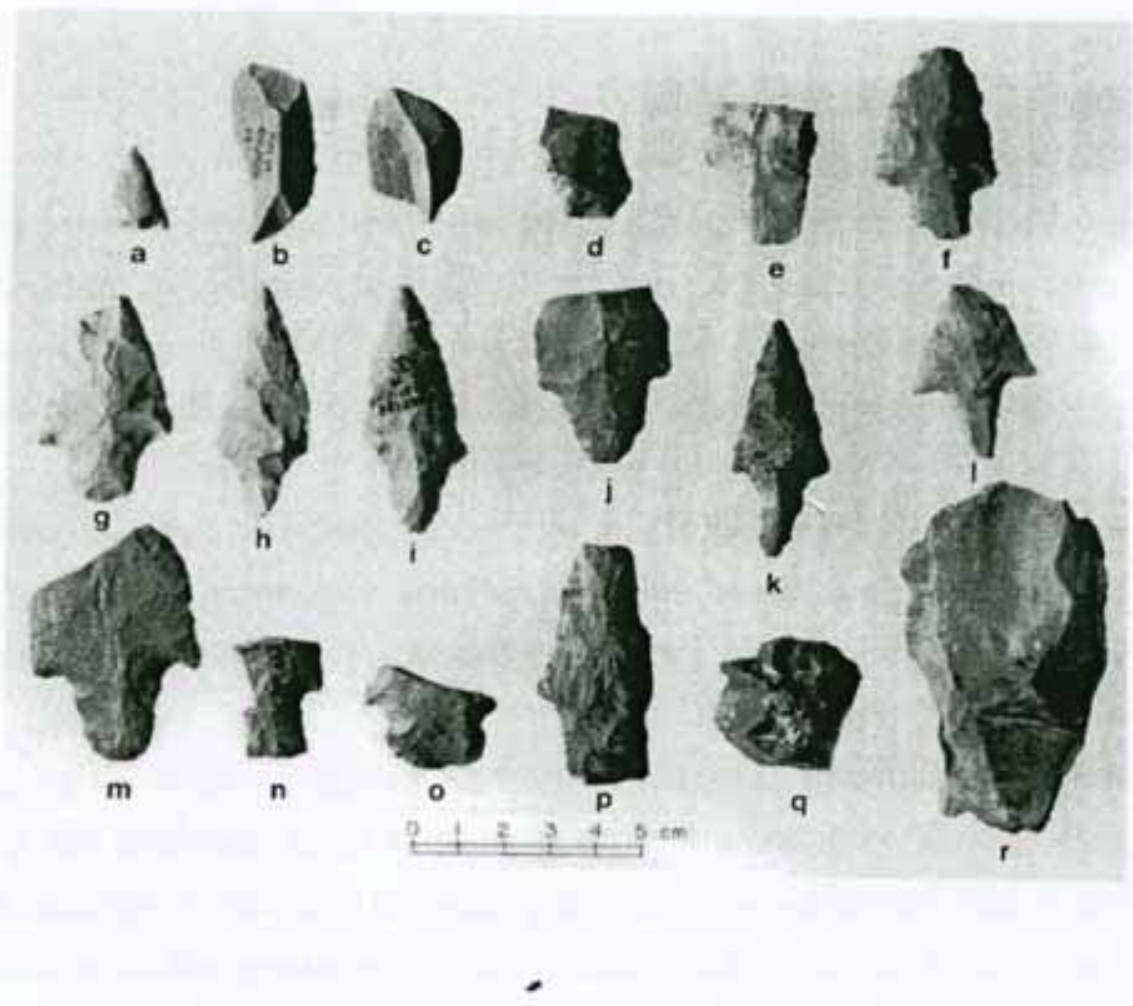

Figure 5. Lithic Tools, Area A.

Table 2. Dart Points.

\begin{tabular}{lcc}
\hline Types/varieties & General Surface & Area A \\
\hline Bulverde & 1 & \\
Wells & 2 & 1 \\
Kent & 3 & 1 \\
Yarbrough & 12 & 2 \\
Gary, var. Camden & 4 & 1 \\
var. LeFlore & 8 & 1 \\
\hline
\end{tabular}

Cutting, scraping, woodworking, and other such activities on bone and wood were also important tasks conducted at the site as based on the flake tools (see Figure 5b-d, q). A single lithic tool used for perforating leather, wood, or bone was found on the site's 
surface (see Table 1); these types of perforators are common on Caddoan sites in the Upper Sabine River basin (Bruseth and Perttula 1981).

Most of the flake tools (about 65 percent) were on pieces of chert collected fron local Sabine River gravels. Another 27 percent of these tools were on quartzite, and the remainder were on petrified or fossil wood; both these materials were also available in loca gravels (Perttula 1984). The analysis of the types of flakes selected for tool use indicates that flakes with a point of applied force (i.e., complete or broken flakes) were preferred along with flake fragments (flakes with a discernable ventral surface but lacking the point of applied force [Sullivan and Rozen 1985:759]). The debris flake type--that is, flakes lacking a striking platform, a bulb of percussion, and with margins that are not intact-comprises less than 10 percent of the unifacial/utilized pieces.

Broken flakes and flake fragments dominate the unused flakes in the Area A assemblage (Table 3). Debris is also common from this part of the site, and complete flakes account for only 15.7 percent of the Area A flakes. The high proportions of broken flakes, flake fragments, and debris, along with the low number of cores, suggest that tool manufacturing activities were important compared to core reduction. The frequency of broken bifaces also hints at the frequency of manufacturing failures.

Unlike the flake tools, where chert was the preferred material, the unused flakes are primarily of coarse and fine-grained quartzites. These quartzites comprise between 63-73 percent of each of the four flake types in the debitage sample from Area A, which indicates their reduction during all phases of tool manufacture (Table 4).

Table 3. Percentages of Flake Types.

\begin{tabular}{lcc}
\hline Flake Types & Area A/General Surface & Area B \\
\hline Complete & 15.7 & 21.1 \\
Broken & 30.1 & 7.9 \\
Fragment & 31.3 & 36.8 \\
Debris & 22.8 & 34.2 \\
\hline TOTALS & 643 & 38 \\
\hline
\end{tabular}


There was a clear selectivity by the Carlisle site inhabitants for chert in tool use. Chert raw materials were about three times as likely to be selected for tools than the other raw materials in the lithic assemblage.

Table 4. Percentage of Flake Raw Materials.

\begin{tabular}{lcc}
\hline Raw Materials & Area A/General Surface & Area B \\
\hline Chert & 23.1 & 21.1 \\
Coarse-grained & 37.8 & 44.7 \\
Quartzite & & 21.1 \\
Fine-grained & 26.6 & 2.6 \\
Quartzite & 8.4 & 10.5 \\
Perrified of Fossil Wood & 4.2 & 38 \\
Ferruginous Sandstone & & \\
\hline TOTALS & 643 & \\
\hline
\end{tabular}

Two small unprovenienced pieces of fire-cracked ferruginous sandstone were found in one of the 1975 test pits at Carlisle. Ferruginous sandstone is available locally in bedrock outcrops of the Queen City Formation.

Few lithics were recovered from the buried Caddoan midden in Area B except for fire-cracked rock, a small assortment of cores, a biface fragement, and 38 pieces of lithic debitage. One fine-grained quartzite Scallorn arrowpoint was found at $80-90 \mathrm{~cm}$ below surface, about $30 \mathrm{~cm}$ below the buried midden (see Table 1).

The Area B cores include core fragments of chalcedony, petrified wood, and a finegrained quartzite. The debitage was dispersed through a meter of alluvial sediments, with about 65 percent of it deriving from the buried midden deposits. The types of flakes present are again suggestive of tool manufacturing byproducts in that fragments and debris account for 71 percent of the Area B flakes (see Table 3). The use of raw materials for tool manufacture is similar between Areas A and B at Carlisle, with quartzites comprising 65.8 percent of the debitage in Area B (see Table 4). The petrified wood biface fragment was found between $40-50 \mathrm{~cm}$.

Sixteen pieces of ferruginous sandstone fire-cracked rock were found in Area B. The small pieces were all recovered in association with the buried midden, being most common $20-40 \mathrm{~cm}$ below surface. 


\section{Ceramics}

A total of 119 sherds were recovered from the test excavations at Area A, along with another 168 sherds from the surface of the upland knoll. About five percent of these ceramics were tempered with bone, with the remainder being grog-tempered. Of the 83 decorated sherds, 51 percent have brushed bodies, 19 percent are incised, 14 percent are punctated, 7 percent are engraved, 4 percent are neck-banded, 2 percent have appliqued designs, and one decorated sherd has both incised and punctated designs. In the main, the brushed sherds derive from the body of everted rim jars with parallel or cross-hatched incised lines, but a brushed carinated bowl is also present (Table 5); this particular vessel has been refired. One characteristic decorative motif for the large jars at Carlisle include cross-hatched incised rims with a horizontal row of punctations on a clay-appliqued fillet at the body/rim juncture, and then vertical brushing on the body (see Figure 14).

Table 5. Ceramic Decorative

Elements.

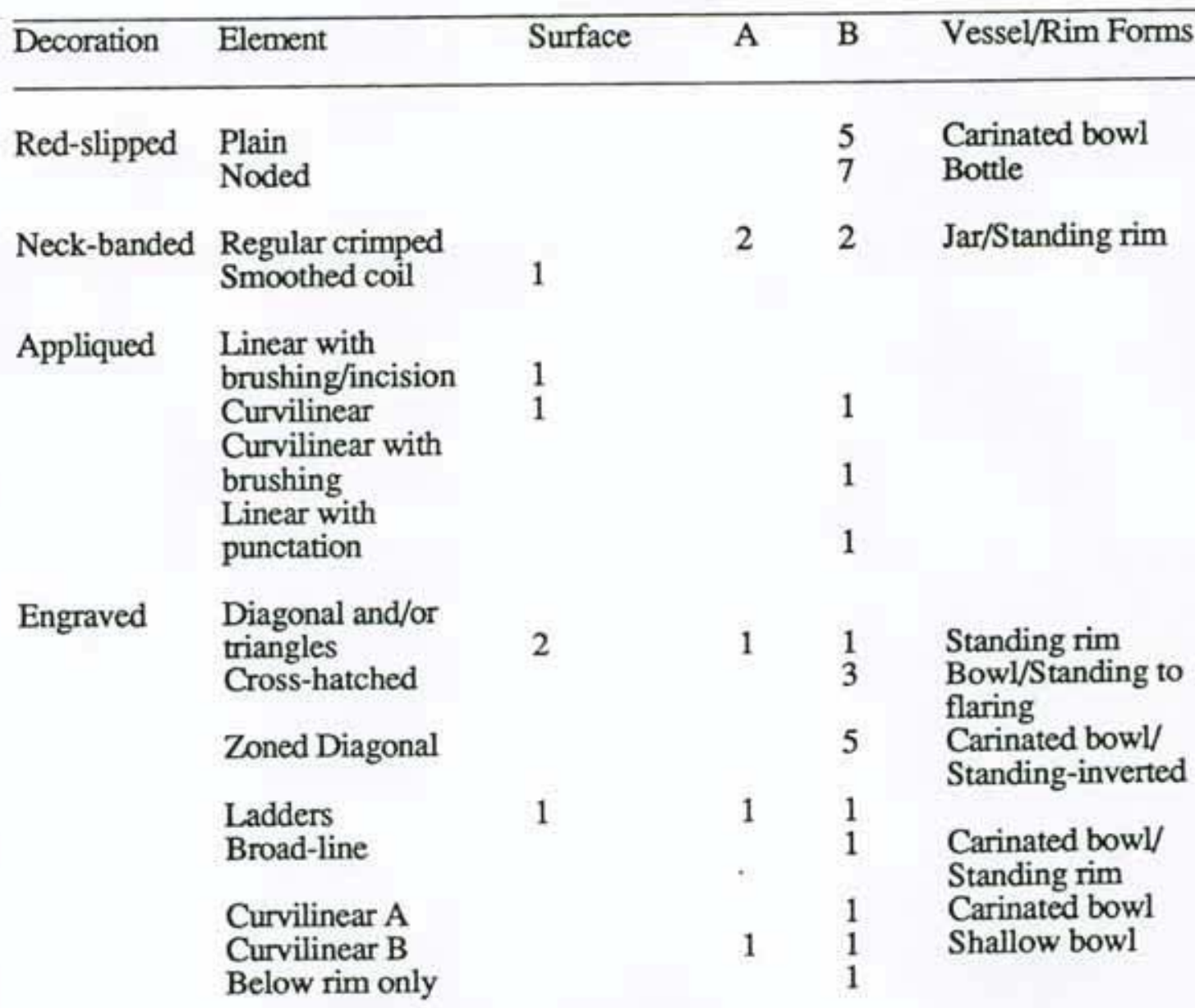


Notes on Northeast Texas Archaeology, No. 1

Table 5. cont.

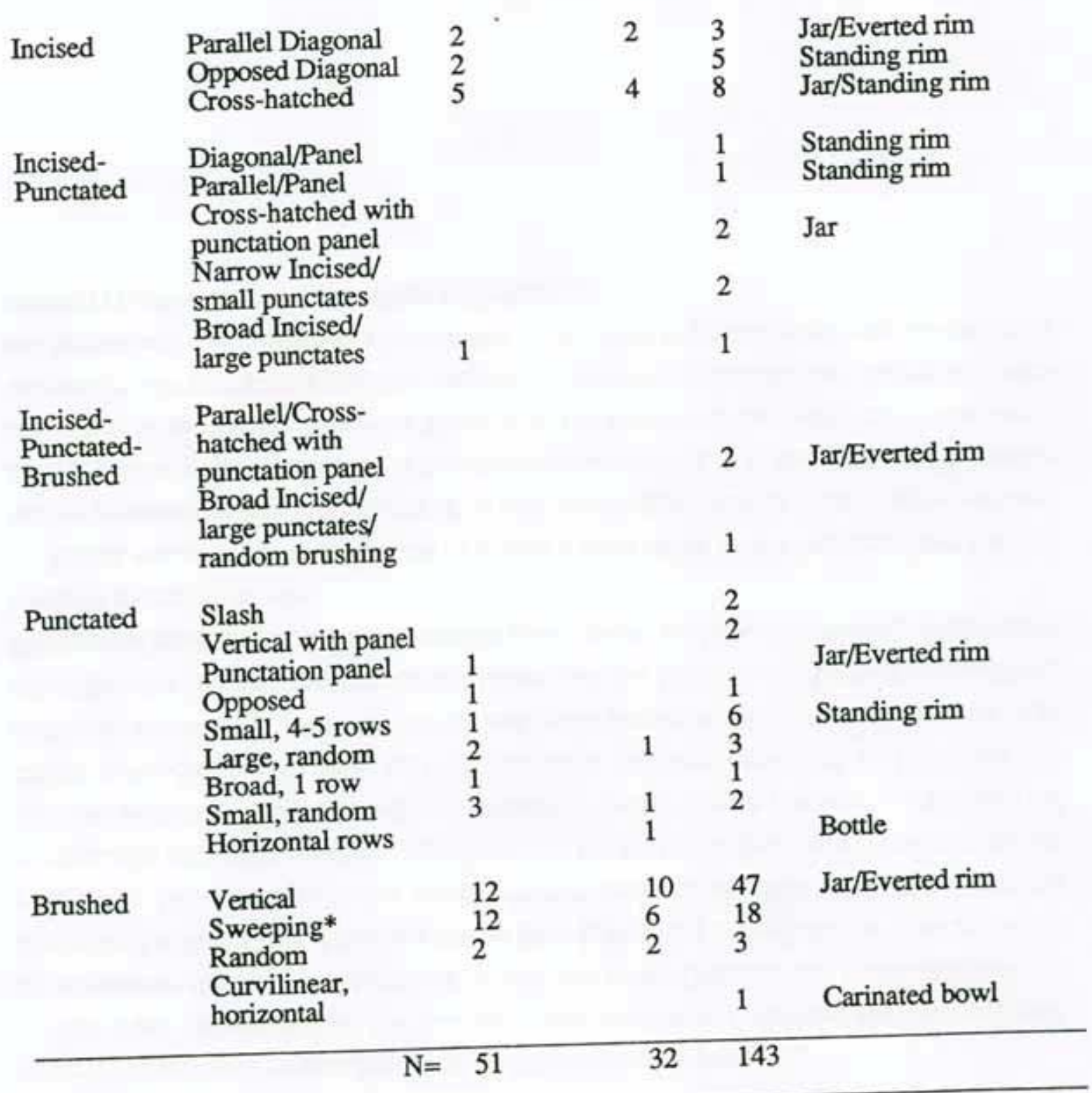

* Bone-tempered

Initially, we were inclined to associate the brushed sherds and brushed-incised jars with a limited Late Caddoan use of the site (Perttula 1986a). It has usually been assumed that brushing is a Late Caddoan vessel surface treatment in Northeast Texas, and the vertical association between the brushed sherds and the rest of the ceramics was poorly known from the 1975 work. The recovery in 1986 in Area B of Maxey Noded Redware bottle sherds found in association on the same occupational surface as a large rim section of an incised-brushed jar with the punctated fillet makes it evident that the brushed ceramics at Carlisle are not from a separate, Late Caddoan, component. 
The neck-banded sherds from Area A are from one or two possible LaRue Neckbanded vessels; the regularly crimped neck-banded coils have been partially smoothed but are still visible (Figure 6a-d). The appliqued sherds have linear and curvilinear designs, and in one case the applique ridge separates fine incised lines and parallel brushed elements on a jar form (see Figure $6 \mathrm{e}, \mathrm{g}$ ). The decorative treatment resembles that seen on Pease Brushed-Incised jars. The engraved sherds from Area $A$ include a pendant triangle motif on a possible Ripley Engraved bowl, as well as curvilinear and "ladder" motifs from sherds in Unit 4S 2E. The engraved sherds are from straight rim bowls and carinated bowls (Figure 7).

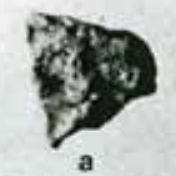

a

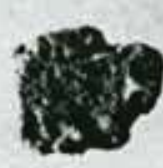

d

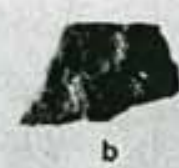

b

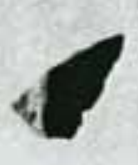

e
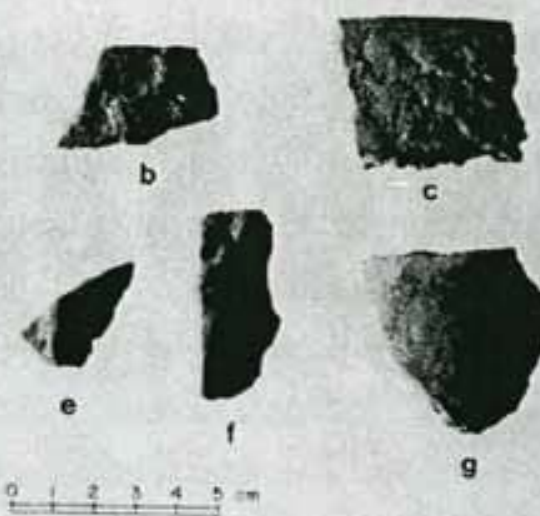

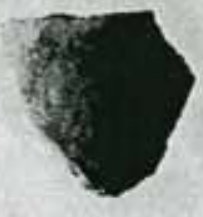

9

Figure 6. Neck-banded and appliqued sherds.

Incised sherds are relatively common in the Area A ceramic assemblage (see Table 5). Both cross-hatched and diagonal incised decorative elements are represented, with cross-hatched sherds accounting for 60 percent of the incised pieces (Figure 8). In general, the incised vessels are large jars with both standing and everted rims.

Unlike in Area B, incised-punctated or incised-punctated-brushed sherds are very rare in Area A at the Carlisle site. The single incised-punctated sherd from Area A has broad incised lines with large fingernail or tooled punctations. 


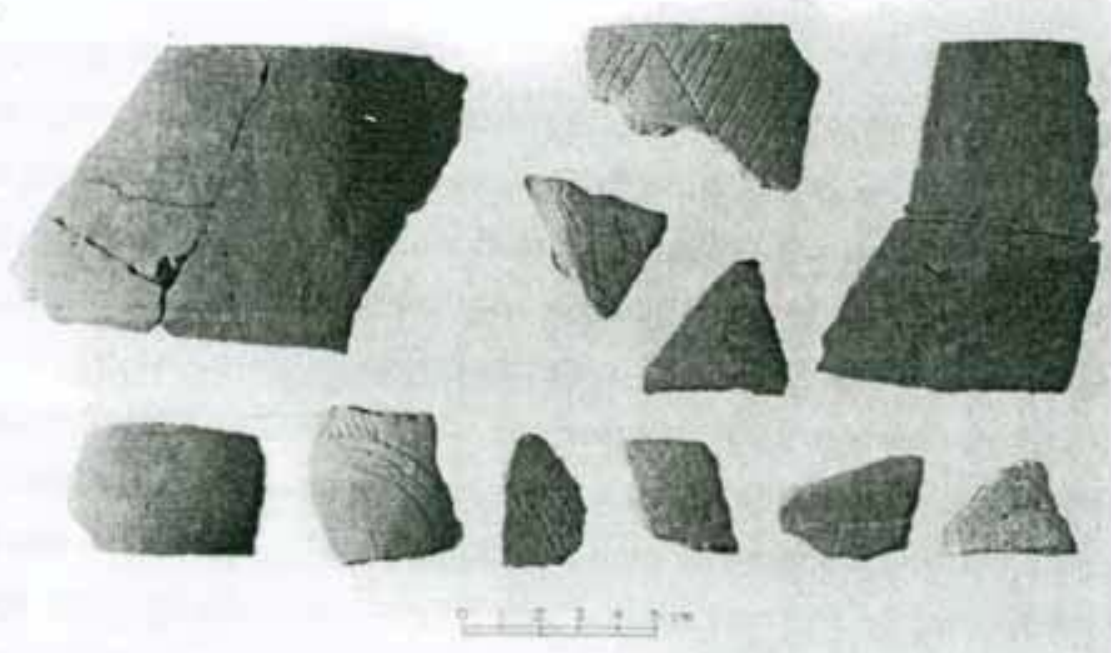

Figure 7. Engraved Sherds.
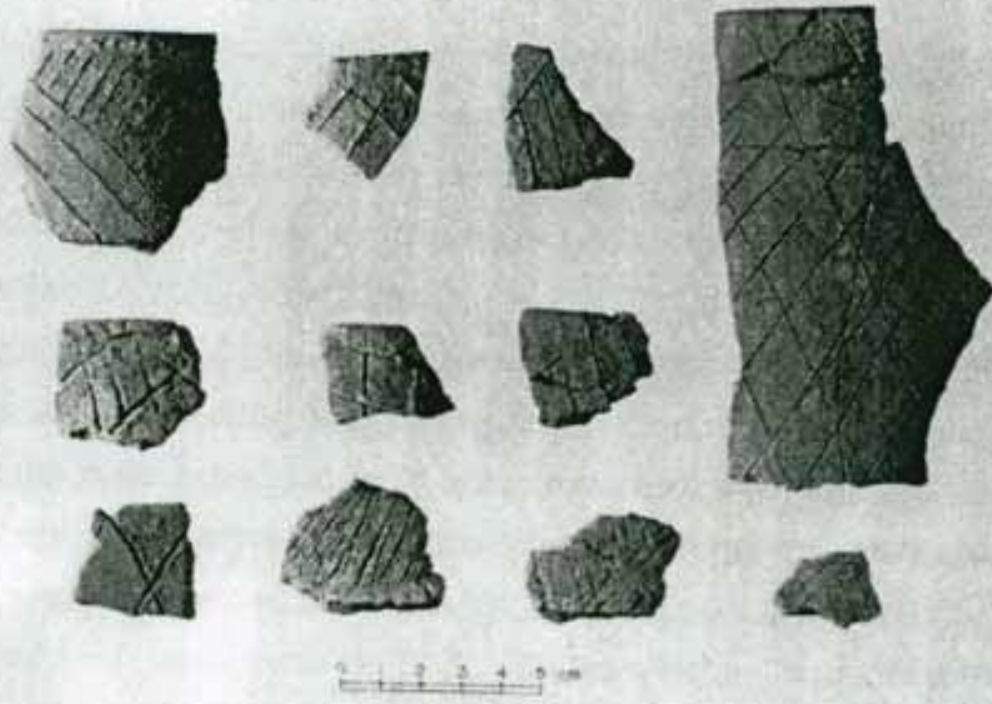

Figure 8. Incised rim and body sherds. 
A variety of punctated sherds are seen in the Area A collection (see Table 5). Most occur in random orientation on the body and/or rim of standing and everted rim jars, with small, large, and broad sizes in the tool or finger punctations themselves (Figure 9). One sherd represents the punctated fillet panel at the base of the rim of large incised-brushed jars; this type of vessel decoration is apparently much more common in Area B (see Table 5). Rows of rim punctations are present on only three sherds from Area A, one from a standing rim jar and another from a bottle.

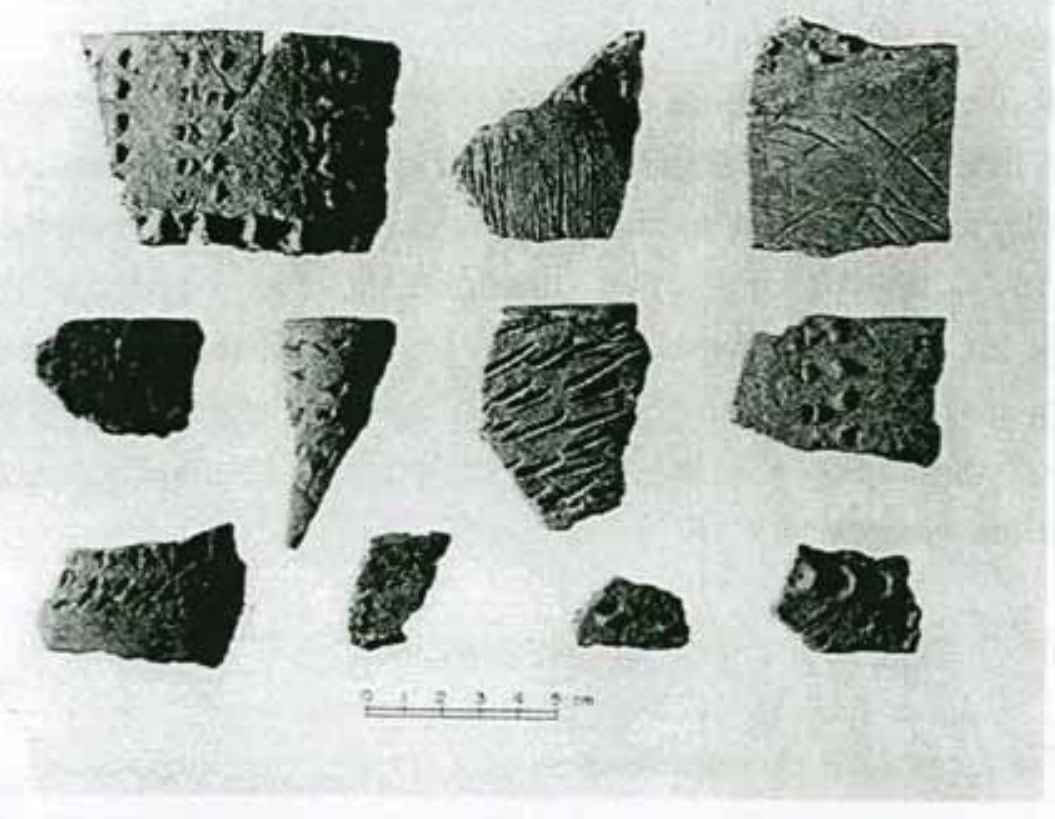

Figure 9. Punctated sherds.

Brushed sherds are well-represented in surface and excavated contexts at Area A. Generally, the brushed sherds represent the bodies of everted rim jars with incised and/or punctated rims (Figure 10). Over thirty sherds of a large cross-hatched incised/brushed jar were recovered from Unit 4S 7E. The vessel body brushing was commonly applied vertically with swaths of grasses before the vessel was fired, but sweeping, curvilinear brush marks account for about 40 percent of the brushed sherds (Figure 11). In a few instances, the brushing was rather randomly placed on the vessel body, and then partially obliterated through vessel finishing and/or use. 


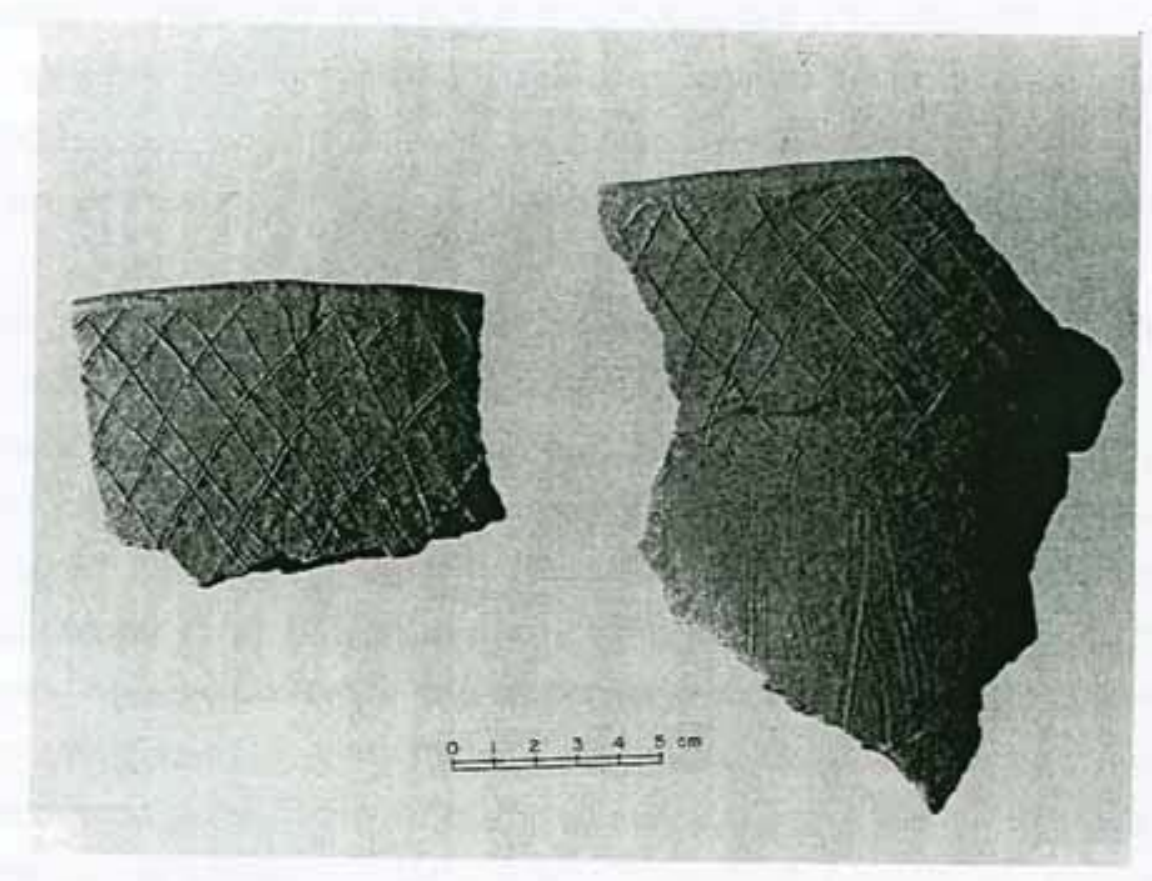

Figure 10. Large incised-brushed jar from Area A.

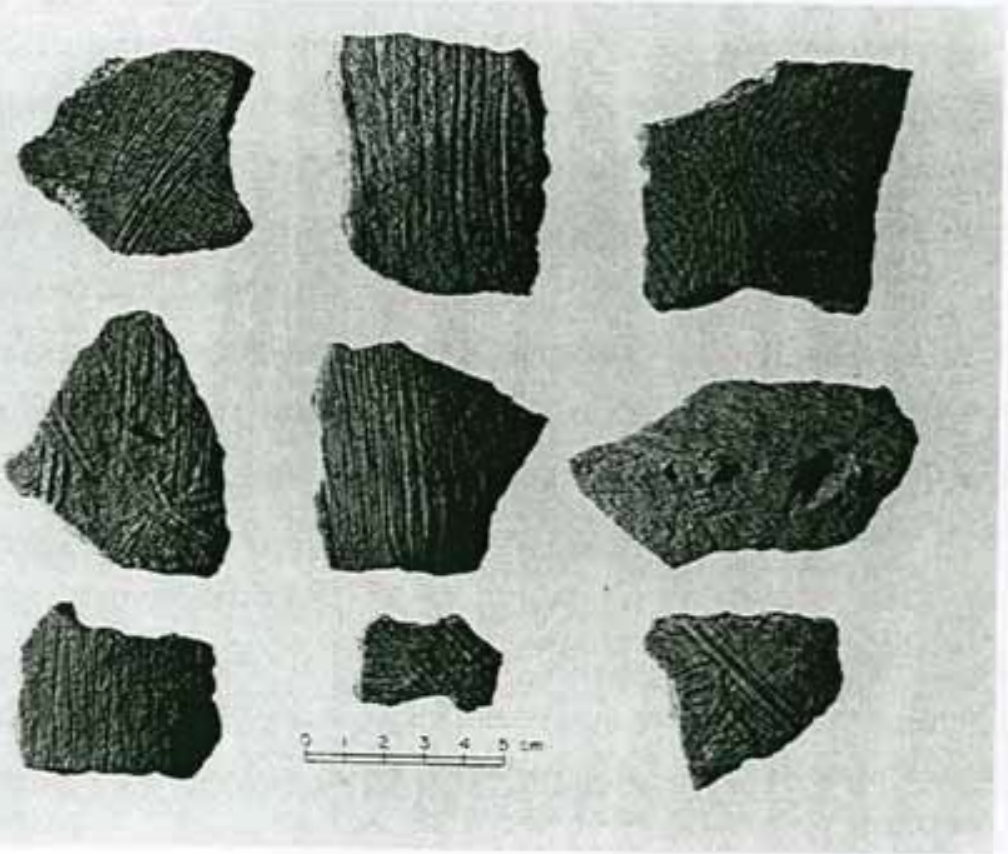

Figure 11. Brushed Sherds. 
The large incised-brushed jars frequently have smudging areas and patches of carbonized organic residue from their apparent use as cooking jars (e.g., Skibo 1992). Analyses of these residues are planned to identify what foodstuffs may have been cooked in these vessels, and thus gain information on vessel contents and possible uses (e.g.,
Heron and Evershed 1993).

Among the plain rims, standing and rolled rims were the two most common forms (Table 6). These derive from deep bowls and jars, and bowls or carinated bowls, respectively (Figure 12). Other plain rims have lip notching, small nodes, or are interior thickened. The latter type of rim form occurs on certain bowls and carinated bowls.

Table 6. Plain rims.

\begin{tabular}{lllll}
\hline Rim Type & Surface & Area A & Area B & Vessel Form \\
\hline $\begin{array}{l}\text { Standing-direct } \\
\text { Lip Notched }\end{array}$ & 6 & 2 & 4 & $\begin{array}{l}\text { Deep bowls } \\
\text { and jars }\end{array}$ \\
$\begin{array}{l}\text { Rim Node } \\
\text { Scalloped }\end{array}$ & 1 & 1 & 1 & \\
Interior Thickened & 1 & 1 & $\begin{array}{l}\text { Bowls and } \\
\text { carinated } \\
\text { bowls } \\
\text { Rowls and } \\
\text { carinated } \\
\text { bowls }\end{array}$ \\
\hline $\mathrm{N}=$ & 10 & 6 & 2 & \\
\hline
\end{tabular}

Characteristics of the Carlisle site, Area B ceramic assemblage include: (1) the motif of cross-hatched engraved triangles pendant from the rim, (2) horizontal engraving, (3) scalloped and interior thickened rims, (4) plain and Sanders Plain carinated bowls and Maxey Noded Redware bottles, and (5) a high frequency of diagonal and cross-hatched incised and incised-punctated vessels. Brushed sherds account for about 48 percent of the decorated sherds.

Plain and noded red-slipped sherds account for about eight percent of the Area B decorated sherds. The plain red-slipped sherds are from carinated Sanders Plain bowls. 
The red-slip was derived from pulverized hematite materials added to a clay wash, then applied to the vessel surface prior to firing. Petrographic and thin-section analyses indicate that these vessels were smoothed and burnished prior to the application of the slip, then burnished and polished after firing (Ferring and Perttula 1987).

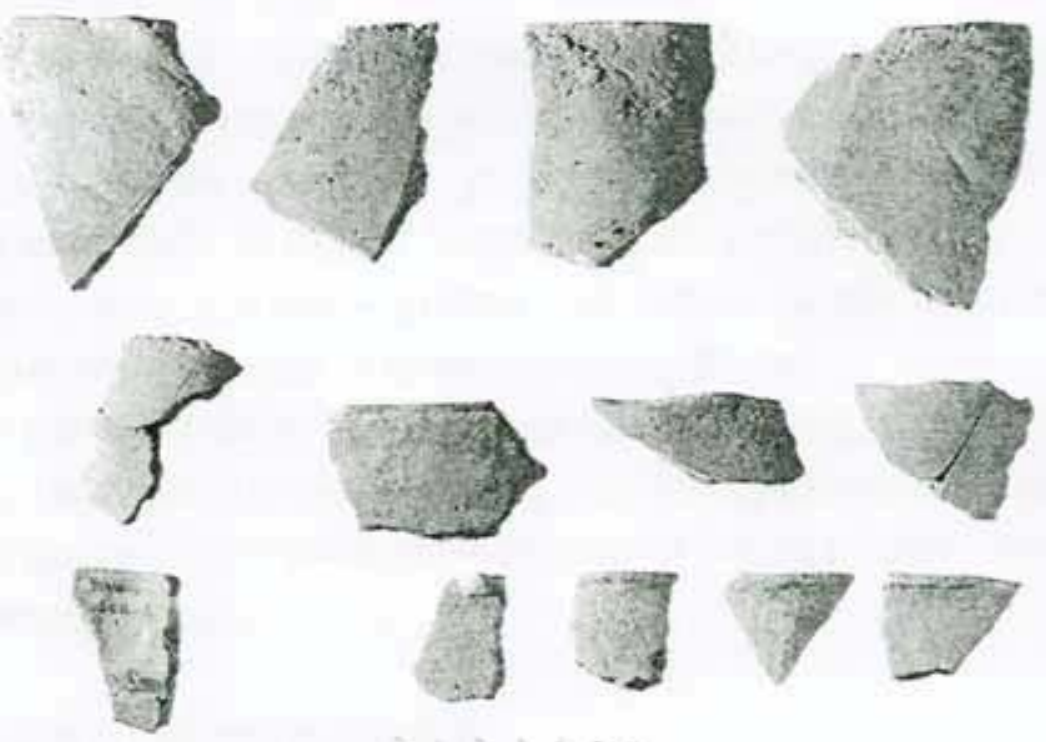

Figure 12. Plain Rims.

The red-slipped noded sherds are from two separate Maxey Noded Redware bottles. These are grog-tempered, squat, long-necked bottles decorated with parallel lines of applique nodes and a red slip added to the exterior vessel surface. The nodes are placed below the neck of the bottle and run vertically from there to just above the base in two to four sets of parallel lines. Another variety of Maxey Noded Redware has sets of fingernail punctates below the bottle neck to replace the nodes (Krieger 1946).

Maxey Noded Redware is an uncommon, but distinctive, Middle Caddoan ceramic type estimated to have been manufactured between about A.D. 1200-1400 (Thurmond 1985:189). At the Sanders site (41LR2), Maxey Noded Redware accounted for only about eight percent of the vessels (Krieger 1946:Table 5). The type appears to have been made by Caddoan peoples living in the area from the Upper Sabine River basin to the Middle Red River. 
Neck-banded and appliqued sherds from Area B account for 3.5 percent of the decorated sherds (see Table 5). The neck-banded sherds are from jars with standing rims. The neck-banding is characterized by regularly crimped, but unsmoothed, coils that overlap to create a shingle-like effect (see Figure 6a-d). In the Upper Sabine River basin neckbanded sherds resembling those from Carlisle have been noted at several sites in Lake Fork Reservoir (Bruseth and Perttula 1981:Table 5-3, 5-8) and the Fred Yarbrough site in Van Zandt County (Johnson 1962:206).

Linear and curvilinear appliqued ridges occur on a few Area B sherds. The applique is typically added to vessel exteriors to divide parallel brushing on vessel bodies.

An interesting assortment of engraved bowl and carinated bowl sherds were recovered from Area B at the Carlisle site (see Table 5 and Figure 7). Decorative elements $\# 9$ and \#10 are from Sanders Engraved bowls; one of the cross-hatched engraved rims has lip notching. Curvilinear and ladder engraved motifs are harder to characterize typologically, but similar decorative elements are seen on pottery from undated Caddoan sites in the Upper Sabine and Upper Neches river basins.

Decorative element \#11 is the most common engraved design in Area B. Represented by five sherds from one carinated bowl, the design consists of fine, zoned diagonal, engraved lines on the rim (Figure 13). Small excised triangles are nested in the angles of the diagonal engraved lines, and the broad lip has diagonal notched lines on it.

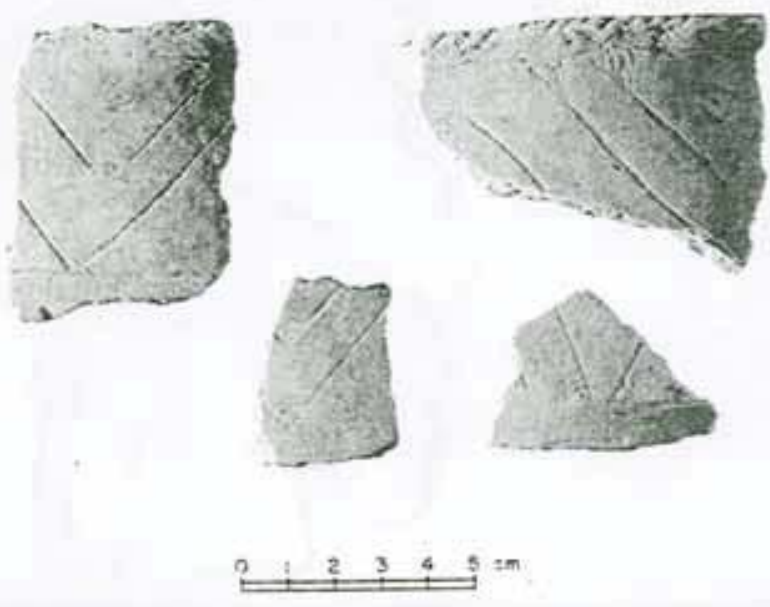

Figure 13. Engraved Vessel, Decorative element \#11. 
Both diagonal and cross-hatched incised sherds from straight and everted rim jars are represented in the Area B ceramic assemblage (see Figure 9). These are probably from Canton Incised and/or Maydelle Incised types.

The majority of the incised-punctated and incised-punctated with vertical brushed sherds, as well as a few of the punctated sherds (decorative element \#28), are from the most diagnostic Carlisle ceramics: the large jars with cross-hatched or parallel-opposed incised lines on the rim, a punctated applique fillet at the rim/body juncture, and a vertical brushed body (Figure 14). Other incised-punctated sherds consist of incised zones at the rim filled with either large or small circular punctations. These sherds are from standing rim jars.
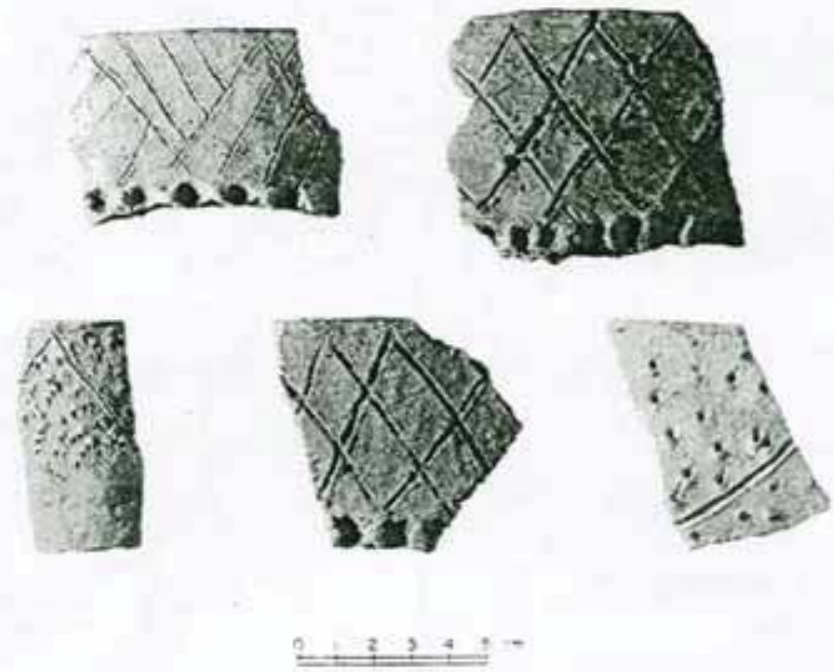

Figure 14. Incised-punctated sherds with appliqued panels.

In addition to the punctated panels on the aforementioned jars (see Table 5), other types of punctated sherds from Area B include a diagonal fingernail-slashed variety from a simple bowl, four to five horizontal rows of small punctations, and random punctations of various sizes (see Figure 9). The horizontal and random punctations are the two most frequent punctate elements. 
About 68 percent of the brushed sherds have vertical brushing marks on the bodies of everted rim jars (see Figure 11) decorated with broad-line incisions and punctations. Sweeping, curvilinear brushing is present on another 26 percent of the brushed sherds, and all these are from a distinctive vessel heavily tempered with bone (instead of the grog used with almost all the rest of the sherds from Carlisle). Finally, one carinated bowl was decorated with curvilinear and horizontal brushing marks on the rim.

Plain rims from Area B are predominantly standing and direct types (see Table 6). Lip-notched and scalloped-rim bowls are also present; these types of lip and rim treatment are notable in Middle Caddoan ceramic assemblages in the Upper Sabine River basin.

Small pieces of burned clay and daub were recovered from both Areas A and B at Carlisle (see Table 1). These are generally rounded and eroded pieces of clay that had been applied to the walls of structures, or were used to line hearths, and became fire-hardened through hearth cooking and/or structure burning. The daub has grass and stick impressions on them.

\section{FAUNAL ANALYSES}

A small but extremely diverse faunal assemblage was obtained in the excavations of Area A and B at the Carlisle site. Represented in the 258 identifiable specimens are eleven species of mammals, one bird species, five species of reptiles, and five fish species:

\section{Mammals}

Deer

Swampljackrabbit

Fox Squirrel

Opossum

Pocket Gopher

Cottonrat

Raccoon

Skunk

Gray Squirrel

cf. Dog

Vole
Birds

Turkey

Fish

Bowfin

Drum

Bass/Sunfish

Gar

Catfish
Reptiles

Box turtle

Softshell turtle Red-eared turtle Map turtle Slider

Most of the faunal remains were recovered in the Area B midden deposits and Feature 1, with about 18 percent recovered from general proveniences in the 1975 investigations (most of this material is also from the Area B midden deposits). In terms of identifiable faunal elements, deer, box turtle, and drum are most common, followed by swamp or jackrabbit, opossum, red-eared turtle, and gar. Fish remains were particularly 
abundant in Feature 1, and in the middle part of the midden deposits (Table 7), as were reptile faunal elements. Mammal remains were particularly common in the general midden deposits.

Table 7. Faunal Analyses.

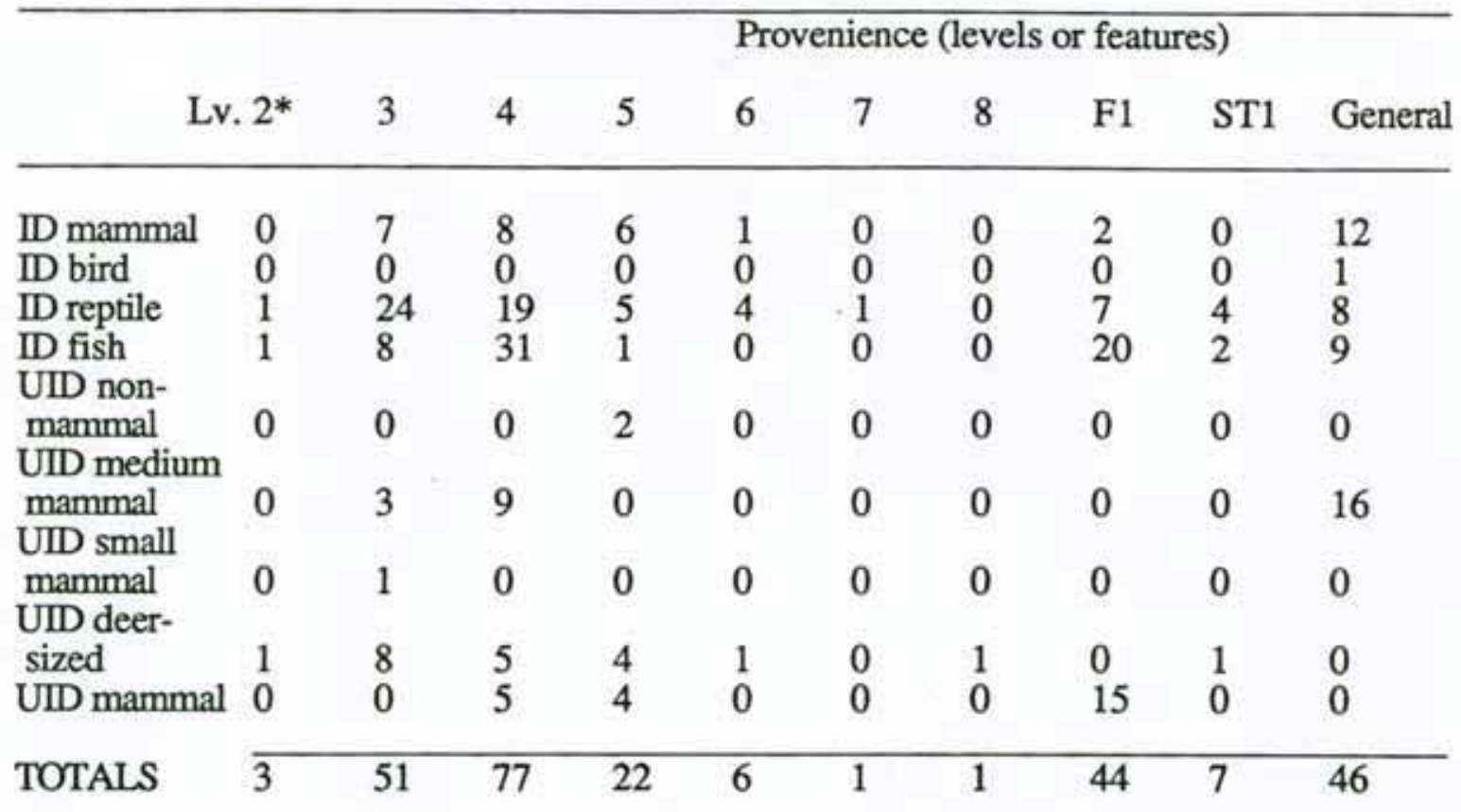

${ }^{*} \mathrm{Lv} .=$ levels, $\mathrm{F} 1=$ Feature $1, \mathrm{ST} 1=$ shovel test $1, \mathrm{ID}=$ identifed, and UID=unidentifed

In general character, the Carlisle faunal assemblage resembles that noted in Formative-Middle Caddoan archaeological sites in the Upper Sabine and Sulphur River basin of Northeast Texas (Perttula and Bruseth 1983; Perttula 1993). The assemblages are diverse, indicating that an assortment of upland, riverine, and aquatic species were exploited for food, with deer the most important mammal species, but turtles and fishes also were valued supplements to the Caddoan diet.

\section{MUSSEL SHELL ANALYSES}

A total of 133 identifiable mussel shells were recovered from the Area B midden. About 60 percent of the mussel shell were not identifiable to species, being represented only by pseudocardinal teeth. The most common mussel shell species included Amblema plicata, Quadrula quadrula, and Tritogonia verrucosa, but a number of other species were identified in the assemblage (Table 8). 
In general, the mussel shell species represented at the Carlisle site preferred muddy and slow moving water from medium-sized streams and rivers, although a few species preferred clear water with sandy bottoms. Both stream conditions can be found on both the Sabine River and Lake Fork Creek.

Table 8. Mussel Shell Analysis

Species

Level $1 \quad 2 \quad \begin{array}{lllllllllllll}3 & 4 & 5 & 6 & 7 & 8 & 9 & \text { FEA. } 1 & \text { ST } 1 & \text { TOTAL }\end{array}$

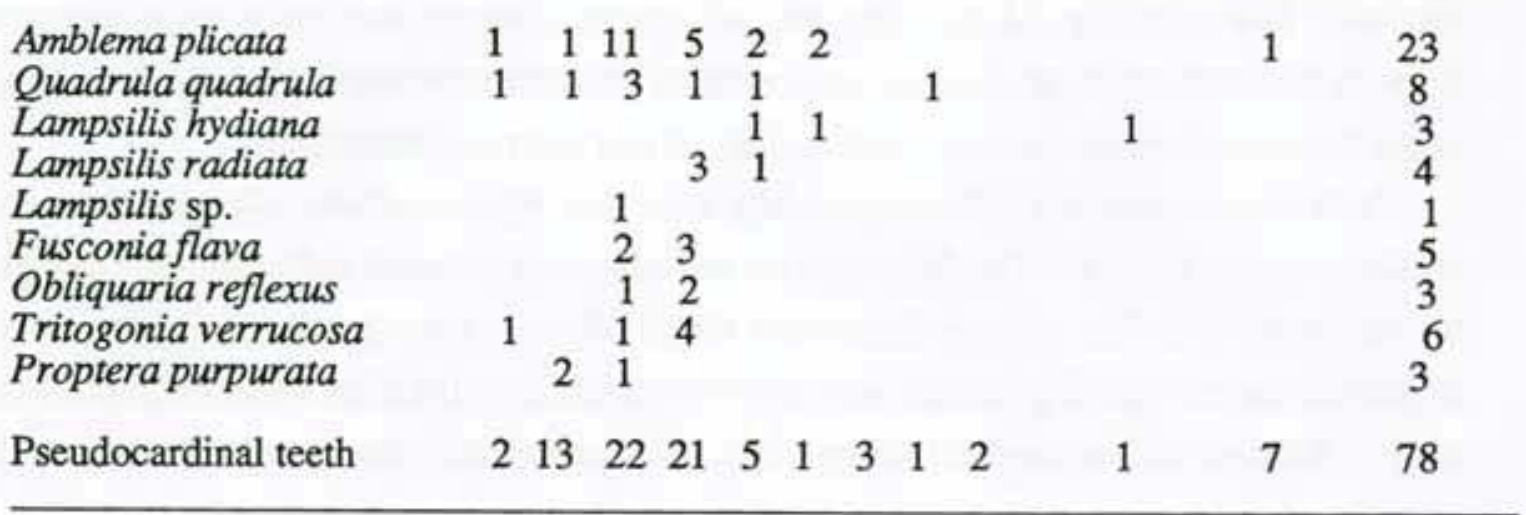

\section{SUMMARY}

This section summarizes the areal contexts and artifact associations from the Carlisle site based on 1970s surface collections and limited test excavations in 1975 and 1986. Since much of the material derives from surface collections, chronological and functional relationships between material remains are based in large measure upon the regional overview of artifact sequences for Northeast Texas proposed by Story (1990).

\section{AreaA}

The earliest occupation at the Carlisle site occurs on the upland projection (Area A). A small Middle Archaic period occupation (ca. 3500-2500 B.C.) is represented by single examples of Bulverde and Wells projectile points, but a Late Archaic component with considerable subsurface depth is probably represented by the Yarbrough darts. One Yarbrough point was recovered in Unit 5S 7E between $80-90 \mathrm{~cm}$ below surface.

Over 51 percent of all the dart points from the Carlisle site are Gary var. LeFlore (dated ca. 450 B.C. to A.D. 250 by Schambach [1982]) and var. Camden (ca. A.D. 250750) projectile points from Area A (see Table 2 ). This suggests that a fairly substantial 
Early Ceramic period occupation was present on the upland landform. No features were noted in the Area A excavations that relate to the Early Ceramic occupation, but much of the lithic debris, broken and finished tools, as well as the unifacial tools, probably can be associated with this occupation. Similar types of Early Ceramic period components are common in the Sabine and Sulphur River drainages, namely archeological deposits with large numbers of Gary points and other lithic tools, no ceramics, and no features (see Fields et al. 1992; Perttula et al. 1993). They appear to represent intensively, but intermittenly, utilized places where tool manufacture and refurbishing activities took place along with the procurement and processing of animal and plant food resources.

A more substantial Caddoan occupation is also present in Area A of the Carlisle site. The test excavations there encountered evidence that a structure probably stood on the upland projection: pieces of daub, a mud-dauber's nest, and several large sherds from brushed vessels that appear to have been refired during structure burning. Additionally, 31 sherds from a large incised/brushed jar were found on what appears to have been a living surface (or house floor?) at about $30-40 \mathrm{~cm}$ below surface (see Figure 11). Ninety percent of the vessel is present, and all of the sherds were recovered at a common depth in Unit 4S 7E. The Area A Caddoan occupation probably represents a small farmstead or houseplace, with the Area B midden as its related trash dump; in fact, several sherds from both areas are conjoinable. Ceramic decorative similarities, and conjoined ceramic pieces, indicate that the Caddoan occupations were generally contemporaneous in Area A and B. The functional character of the Caddoan component at Carlisle is basically the same as that noted throughout the Upper Sabine River Basin.

\section{Area B}

This area contains a buried Caddoan midden dated to A.D. $1410+/-60$ (uncorrected). The midden was concentrated between $20-55 \mathrm{~cm}$ below surface and contained an abundance of mussel shell, faunal remains, carbonized seed fragments and nutshells, and ceramic sherds. ${ }^{1}$

The same types of ceramic decorative styles and vessel forms noted in Area A are present in Area B (see Table 5). By far the most common vessel form present was a cooking jar with an everted rim, and these were decorated with cross-hatched incised lines and punctated marks on the rim and vertically brushed bodies. The punctated marks were commonly applied on an appliqued fillet at the rim/body juncture (see Figure 12). Plain

1 This ecofactual material has not been thoroughly examined by a paleobotanist to date. 
carinated bowls and noded bottles with a hematite slip were represented only in Area B, while a variety of carinated and shallow bowls were found in both Area A and B that had mainly diagonal or cross-hatched engraved lines on them.

Scallorn and Bassett arrowpoints were recovered from both Areas A and B.

\section{CHRONOLOGICAL AND CULTURAL AFFILIATION OF THE CADDOAN OCCUPATION}

Because of the limited amount of archaeological research conducted on the Sabine River, the few available radiocarbon dates from the region, and the nature of the Carlisle site ceramic assemblage itself, the chronological and cultural affiliations of the Caddoan occupation at the site are not clear. Of particular significance is the high frequency of brushed cooking jars from the site.

Admittedly, the absolute percentage of brushed sherds is skewed due to the recovery of most of a large brushed-incised jar in situ in Area A; nevertheless, brushed sherds are common in the Area A and B ceramic assemblages (see Table 5). In nearby Three Basins subcluster sites of the Titus phase, like Goldsmith (41WD208) and Steck (41WD529), brushed utility wares are not particularly common (Thurmond 1990; Perttula, Skiles, and Yates in press), and engraved sherds are four to five times more common in sherd assemblages. In Lake Fork Reservoir, brushed utility wares are extremely rare, and occur only in Late Caddoan Titus phase contexts (Bruseth and Perttula 1981).

On the south side of the Sabine River, however, at sites such as Bryan Hardy (41SM55) (only $25 \mathrm{~km}$ from Carlisle) and Emma Sanford (41SM57), excavated by Mr. Sam Whiteside in the 1950 s, brushed ceramics are quite common. Indeed, they are as frequent as any other decorated sherds in the ceramic assemblages. Sites 41WD245 and CXA (41WD507) on the north side of the Sabine River also have similar ceramic assemblages, particularly with respect to the numbers of brushed sherds and to some of the distinctive styles of engraved ceramics.

One of the engraved carinated bowls from Carlisle has an alternating triangular motif, and the lip has been regularly notched. A very similar carinated engraved bowl was uncovered in Burial 2 at the Bryan Hardy site by Sam Whiteside, along with a pinched pedestaled jar (Killough Pinched?) with strap handles, a plain bowl, and a tiny effigy bowl. The Bryan Hardy site is undated, but an initial examination of the excavated ceramic assemblage suggests a probable date range between about A.D. 1200-1400 (Perttula et al. 1986:81).

The A.D. $1410+/-60$ date from the Carlisle site seems consistent with the frequency of brushed ceramics, the presence of interior thickened rims, and the recovery of 
Maxey Noded Redware vessels from the site. A thermoluminescence (TLM) date of ca. A.D. 1280 (Alpha-2398) was obtained from an interior thickened Sanders Plain vessel at site 41WD117 on Big Sandy Creek, while another TLM date of ca. A.D. 1400 (Alpha2397) was secured on a Maxey Noded Redware vessel from another site in that drainage (Perttula et al. 1986:484). Similar interior thickened rims and lip notches have also been noted in the ceramics at the nearby Yarbrough (41VN6) and Limerick (41RA8) sites in the Upper Sabine River basin (Johnson 1962:Figure 23i; Duffield 1961:88).

Radiocarbon and TLM dates on Titus phase sites in the Upper Sabine River basin fall after about A.D. 1450 (Bruseth and Perttula 1981; Perttula et al. 1986), and it is possible that the occupation at Carlisle is not contemporaneous with the Titus phase. Perhaps, then, the affiliation of the Caddoan component at Carlisle lies with the heretofore poorly known occupations along and parallel to the Sabine River valley, and not with Titus phase Three Basin subcluster groups on Caney, Dry, and Big Sandy creeks in the Upper Sabine River basin, or with Sanders phase groups along the woodland border areas of Northeast Texas. Among the latter groups, settlements are distributed almost exclusively along tributaries and headwater areas of streams rather than to the major streams such as the Sabine River.

\section{CONCLUSIONS}

Caddoan middens roughly contemporaneous with the Carlisle site are known throughout the Upper Sabine River basin, all located on major streams like the Sabine River, Lake Fork Creek, and Caney Creek. These middens represent small habitation areas of fairly brief occupational span, and usually occur as related house and trash midden components at hamlets and probable farmsteads. Sites such as 41WD245, CXA (41WD507), Son Gibson (41WD1), Yarbrough, Area B (Johnson 1962), Taddlock (41WD482), and Spoonbill (41WD109) are only a few of the middens that have been excavated over the last 50 years in the region. The Carlisle Caddoan occupation generally resembles these sites in functional character, although the geomorphological context/location on the floodplain, the relative abundance of freshwater mussel shell, and the frequency of brushed sherds are specific differences between Carlisle and these other sites.

The Carlisle occupation represents a ca. A.D. 1400 small farmstead or houseplace that shares more similarities in ceramic styles with sites on the Sabine River than it does with generally contemporaneous Titus phase occupations upstream in the Lake Fork Creek drainage. Considerable refinement in cultural assemblage character and chronological 
sequences are still necessary, however, to understand more adequately the regional significance and social differentiation of the Caddoan use on this part of the Sabine River itself.

There is still a great need for the development of a reliable chronological framework for the Caddoan period occupations in the Upper Sabine River basin (see Story 1990). Isolating distinctive chronological components in space and time, combined with the identification of discrete single component assemblages, has to be done if archaeological units are to be related to regionally meaningful socio-cultural entities (Johnson 1987), and if we are to move past simple and basic settlement patterning questions.

Every effort should be made to investigate depositional contexts such as those at Carlisle where ecofactual remains might be preserved in cultural association. Certainly sites such as Taddlock, Spoonbill, and Carlisle exist where well-preserved subsistence data can be obtained, but these types of sites have not really been the focus of intensive study in the Upper Sabine River basin. Obviously, the systematic recovery and analysis of faunal and floral remains will contribute immeasurably to the full consideration of Upper Sabine River basin Caddoan lifeways.

Finally, an understanding of the regional paleoenvironmental and geomorphological record is an integral aspect of attempts to conceptualize prehistoric cultural adaptions. Moreover, these types of investigations may help to locate contexts such as those at Carlisle where buried archaeological deposits are present. Currently, the overall paleoenvironmental record for Northeast Texas is poorly known (Bryant and Holloway 1985; Story 1990), although the potential to recover significant information on Late Holocene environments for the basin is good (e.g., Perttula et al. 1986:322).

In each case, the potential exists with the data base already in hand to carry through exciting and useful research endeavors in Caddoan archaeology in the Upper Sabine River basin. The problem now is to turn that potential into reality by considering broader concepts of cultural change beyond simply basic temporal-spatial analyses. The Carlisle site contains much of the data we need to forge new understandings of Northeast Texas prehistory.

\section{REFERENCES CITED}

Bruseth, James E. and Timothy K. Perttula

1981

Prehistoric Settlement Patterns at Lake Fork Reservoir. Report No. 2. Texas Antiquities Committee, Texas Antiquities Permit Series. Texas Historical Commission, Austin. 
Bryant, Vaughn M. and Richard G. Holloway

1985 A Late Quaternary Paleoenvironmental Record of Texas: An Overview of the Pollen Evidence. In Pollen Records of Late-Quaternary North American Sediments, edited by Vaughn M. Bryant and Richard G. Holloway, pp. 3970. American Association of Stratigraphic Palynologists Foundation, Dallas.

Bureau of Economic Geology

1965 Geologic Atlas of Texas, Tyler Sheet. Bureau of Economic Geology, The University of Texas, Austin.

Duffield, Lathel F.

1961 The Limerick Site at Iron Bridge Reservoir, Rains County, Texas. Bulletin of the Texas Archeological Society 30:51-116.

Ferring, C.Reid and Timothy K. Perttula

1987 Defining the Provenance of Red Slipped Pottery from Texas and Oklahoma by Petrographic Methods. Journal of Archaeological Science 14:437-456.

Fields, Ross C., Eloise F. Gadus, L. Wayne Klement, C. Britt Bousman, and Jerrilyn B. McLerran

1992 Excavations at the Tick, Spike, Johns Creek, and Peerless Bottoms Sites, Cooper Lake Project, Delta and Hopkins Counties, Texas. Reports of Investigations No. 91. Prewitt and Associates, Inc., Austin. Review Draft.

Heron, Carl and Richard P. Evershed

1993 The Analysis of Organic Residues and the Study of Pottery Use. In Archaeological Method and Theory, Volume 5, edited by Michael B. Schiffer, pp. 247-284. The University of Arizona Press, Tucson.

Johnson, Leroy, Jr.

1962 The Yarbrough and Miller Sites of Northeastern Texas, with a Preliminary Definition of the LaHarpe Aspect. Bulletin of the Texas Archeological Society 32:141-284.

1987 A Plague of Phases:Recent Sociocultural Taxonomy in Texas Archeology. Bulletin of the Texas Archeological Society 57:1-26.

Krieger, Alex D.

1946 Culture Complexes and Chronology in Northern Texas. Publication No. 4640. The University of Texas, Austin.

Perttula, Timothy K.

1984 Patterns of Prehistoric Lithic Raw Material Utilization in the Caddoan Area: The West Gulf Coastal Plain. In Prehistoric Chert Exploitation- Studies from the Midcontinent, edited by B.M. Butler and E.E. May, pp. 129-148. Occasional Paper No. 2. Center for Archaeological Investigations, Southern Illinois University, Carbondale.

1986 Archeological Reconnaissance in the Waters Bluff and Upper Little Cypress Reservoirs, Gregg, Harrison, Smith, Upshur, and Wood Counties, Texas. Report submitted to the Bureau of Reclamation by Prewitt and Associates, Inc., Austin. 
Perttula, Timothy K.

1986a The Carlisle Site (41WD46) in the Upper Sabine River Basin. Paper presented at the 1986 Caddo Conference, Little Rock, Arkansas.

1993 The Development of Agriculture in Northeast Texas before A.D. 1600. In Archeology of the Eastern Planning Region, Texas: A Planning Document, edited by Nancy Adele Kenmotsu and Timothy K. Perttula. Cultural Resource Management Report No. 3. Department of Antiquities Protection, Texas Historical Commission, Austin. In press.

Perttula, Timothy K. and James E. Bruseth

1983 Early Caddoan Subsistence Strategies, Sabine River Basin, East Texas. Plains Anthropologist 28:9-21.

Perttula, Timothy K., Bob D. Skiles, and Bonnie C. Yates

in press The Goldsmith Site (41WD208): Investigations of the Titus phase in the Upper Sabine River Basin, Northeast Texas. Bulletin of the Texas Archeological Society 61.

Perttula, Timothy K., Ross C. Fields, James E. Corbin, and Nancy A. Kenmotsu

1993 The Emergence of Sedentism in the Northeast Texas Archeological Region, ca. 500 B.C. to A.D. 1000 . In Archeology of the Eastern Planning Region, Texas: A Planning Document, edited by Nancy Adele Kenmotsu and Timothy K. Perttula. Cultural Resource Management Report No. 3. Department of Antiquities Protection, Texas Historical Commission, Austin. In press.

Perttula, Timothy K., Bob D. Skiles, Michael B. Collins, Margaret C. Trachte, and Fred Valdez, Jr.

1986 "This Everlasting Sand Bed": Cultural Resources Investigations at the Texas Big Sandy Project, Wood and Upshur Counties, Texas. Reports of Investigations No. 52. Prewitt and Associates, Inc., Austin.

Schambach, Frank F. 1982

An Outline of Fourche Maline Culture in Southwest Arkansas. In Arkansas Archeology in Review, edited by N.L. Trubowitz and M.D. Jeter, pp. 132197. Arkansas Archeological Survey, Research Series No. 15. Fayetteville.

Skibo, James 1992

Pottery Function: A Use-Alteration Perspective. Plenum Press, New York.

Skiles, Bob. D., James E. Bruseth, and Timothy K. Perttula 1980

A Synthesis of the Upper Sabine River Basin Culture History. The Record (Newsletter of the Dallas Archeological Society) 36 (1):1-12.

Story, Dee Ann 1990

Cultural History of the Native Americans. In The Archeology and Bioarcheology of the Gulf Coastal Plain, by Dee Ann Story, Janice A. Guy, Barbara A. Burnett, Martha Doty Freeman, Jerome C. Rose, D. Gentry Steele, Ben W. Olive, and Karl J. Reinhard, pp. 163-366. Arkansas Archeological Survey, Research Series No. 38. Fayetteville. 
Sullivan, Alan P. and Kenneth C. Rozen

1985 Debitage Analysis and Archaeological Interpretation. American Antiquity 50:755-779.

Thurmond, J. Peter

1985 Late Caddoan Social Group Identifications and Sociopolitical Organization in the Upper Cypress Basin and Vicinity, Northeastern Texas. Bulletin of the Texas Archeological Society 54:185-200.

$1990 \quad$ Archeology of the Cypress Creek drainage basin, Northeastern Texas and Northwestern Louisiana. Studies in Archaeology No. 5. Texas Archeological Research Laboratory, The University of Texas, Austin.

Wilson, A.M. and A.T. Jackson Notes. MS on file, Texas Archeological Research Laboratory, The University of Texas at Austin. 